\title{
on the Solving of Endless Cycle of Power from Centralization to Decentralization in Fiscal System-Take Reform of Tax Sharing System in 1994 as An Example
}

\author{
Dechao Sun \\ College of Administration University of Jilin Changchun, Jilin Province, China \\ sundechao799@163.com
}

\begin{abstract}
The reform of tax sharing system in 1994 elevated the proportion of central fiscal revenues to overall fiscal revenues in a short time. However, the local extra-budgetary funds also expanded rapidly, which made the ratios of central disposable revenues ( including budgetary funds and extra-budgetary funds ) to overall disposable revenues lower. Therefore, the reform of tax sharing system in 1994 did not arrive at the potential target. The reform of tax sharing system in 1994 is not isolated, and it is only one phase of an endless cycle of power from centralization to decentralization in fiscal system of China since P.R. China was founded. The endless cycle of power from centralization to decentralization, and the prevailing opportunism in fiscal system result from the fact of being lack of rational, perspicuous, stable and compatible rules between the central government and local governments firstly, and secondly result from the absence of rational relations of power and interest between the central government and local governments. To rationalize fiscal system, first of all, China should try its effort to redesign the formulation and implementation between the policies and laws, and secondly, China should devote itself to the readjustment of the fiscal resources and power between the central government and local governments.
\end{abstract}

Index Terms: tax sharing system; fiscal revenues; disposable revenues

\section{I . Reform of tax sharing system in 1994 increasing the ratios of central fiscal revenues to total fiscal revenues}

Given the drawbacks of fiscal contract system, the central government decided to increase the ratio of central fiscal revenues to total fiscal revenues through recentralization in early 1990s. Reform of tax sharing system in 1994 regards rebuilding finance as the content, and thinks of strengthening capacity of transregional distribution of the central government as the object. Reform of tax sharing system in 1994 increased the ratios of central fiscal revenues to total fiscal revenues in a short time through ensuring the dominant position of central fiscal revenues in total fiscal revenues, which reverses the overall descending trend of the ratios of central fiscal revenues to total fiscal revenues since 1984. Since the reform in 1994, from the aspect of ratio, the ratios of central fiscal revenues to total fiscal revenues were lower than 50\% from 1996 to 1998 , but the ratios were generally close to or over $55 \%$ in other years. From the perspective of increasing tendency of this ratio, although the ratios descended continuously from 1994 to 1997, the ratios generally showed a steady increasing tendency since 1997.

\section{II . The reform of tax sharing system in 1994 and the ratio of central disposable revenues to total disposable revenues}

Fiscal revenues and disposable revenues are different. The disposable revenues of governments are actually owned by the governments, which includes budgetary funds, extrabudgetary funds and extra-system funds. Since reform of tax sharing system in 1994, the fiscal burden of the central government has been relieved and the fiscal basis of macro control has been recovered, but the local extra-budgetary funds also expanded quickly. Even the ratios were low from 1994 to 1996, the ratios of local extra-budgetary funds to total extra-budgetary funds were from $75.7 \%$ to $86.8 \%$. From 1997 to 2008, the ratios of local extra-budgetary funds to total extra-budgetary funds always exceeded 90\%. From 1997 to 1998, and 2009, the ratios were even near to 95\%. Therefore, the majority of extra-budgetary funds is controlled and used by local governments. Lots of local extra-budgetary funds make local fiscal revenues less than local disposable revenues, which includes local budgetary funds and local extrabudgetary funds. Large extra-budgetary funds also make the ratio of central disposable revenues to total disposable revenues lower. Except for 2007, 2008 and 2009 when the ratios exceeded $49 \%$, the ratios were centralized about $40 \%$. Therefore, tax system reform in 1994 is far from achieving the intended goals.

In China's practice of financial management, the disposable revenues only include budgetary funds when calculating disposable revenues of one level of government. Extra-budgetary funds are usually calculated separately. In fact, extra-budgetary funds are also disposable revenues of the governments. Therefore, the disposable revenues of the central government and local governments include budgetary funds and extra-budgetary funds. Further, the disposable revenues include extra-system funds except for budgetary funds and extra-budgetary funds. Compared with the central government, local governments and agencies are close to those they serve, and the benefits and objectives of public services provided by local governments are easy to define. This means that local governments more easily obtain revenues through charging than the central government. ${ }^{\text {[1] }}$ Therefore, local extra-system funds are the largest amount of all extra-system funds. If counting extra-system funds, the 
ratios of central disposable revenues to total disposable funds will further descend.

\section{III - The endless cycle of power from centralization to decentralization in fiscal system}

Recalling the adjustment and change of fiscal system since P.R. China being founded, it is not difficult to find the orbit of endless cycle of power from centralization to decentralization. Under the situation of planned economy, the highly fiscal centralization made the local governments lack positivism and responsibility, and also made the imbalance of central fiscal revenues and central fiscal expenditures enlarge. The central fiscal expenditures were much more than central fiscal revenues from 1959 to 1979. From 1959 to 1970, the fiscal burden of the central government was all within -20 billion Yuan. From 1971 to 1979, the fiscal burden of the central government was all over -30 billion Yuan. In 1979, the fiscal burden of the central government was as high as 42.374 billion Yuan. Therefore, the central government experienced serious fiscal burden more than 20 years since 1959. Since reform and opening up, the central government chose fiscal decentralization, also called eating from separate pots (fenzaochifan), which means that the central government endowed the local governments with tax levying power and expenditure power, and also made the local governments endure much more responsibility than before. While incentiving the positivism and responsibility of the local governments, the situation of "the centre has policy and localities has countermeasures" was also popular, which resulted in "the centre is poor but localities are rich" (zhongyangqiongdifangfu). From the ratio of central fiscal revenues to total fiscal revenues, it was within $40.5 \%$ from 1980 to 1993, and it was below 30\% from 1980 to 1982, and from 1991 to 1993 . From the increasing tendency of the ratio, there were two phrases. The first phrase is from 1980 to 1984, when the ratios of central fiscal revenues to total fiscal revenues increased continuously. The second phrase is from 1984 to 1993, when the ratios of central fiscal revenues to total fiscal revenues showed overall descending tendency. In 1993, the ratio of central fiscal revenues to total fiscal revenues was as low as $22.0 \% .{ }^{[2]}$ The former period means that eating from separate pots can relieve the fiscal burden of the central government. The last period means that eating from separate pots is beneficial for local governments to collect fiscal revenues in the long run, which also means that it is necessary and important to reform eating from separate pots. Since reform of tax sharing system in 1994, the central government elevated the ratio of central fiscal revenues to total fiscal revenues through remaking rules, which increased from 22.0 in 1993 to 55.7 in 1994 . At the same time, local extra-budgetary funds also expended quickly, which forms the financial basis for local protectionism, and also makes macro control from the central government much more difficult than before. Why does the fiscal system cycle of power from centralization to decentralization endlessly? How to make fiscal system develop stably in the long run?

\section{IV . Solutions about the endless cycle of power from centralization to decentralization in fiscal system}

4.1 Institutional reasons and solutions for the endless cycle of power from centralization to decentralization in fiscal system

The endless cycle of power from centralization to decentralization and prevailing optimism result from there being not rational, definite, stable and compatible rules. Because the rules are not rational, definite, stable and compatible, the local governments doubt whether the central government obey the rules, while considering the central government usually adjusted central and local fiscal relations through changing rules. If local governments can estimate that the central government can choose optimistic behaviors after the rules are made, local governments only have two choices, one is choosing optimistic behaviors, another is making rules to ensure that the central government will not choose optimistic behaviors. ${ }^{[3]}$ Absolutely, the second choice is better than the first one. However, if the rules of limiting the central government are difficult to make, the local governments have to choose the first choice. That is, local governments will choose optimistic behaviors whether the central government choose optimistic behaviors or not. It is necessary for regulating central and local fiscal relations through rational, definite, stable and compatible rules in order to regulate fiscal system and prevent optimistic behaviors. It also means that the adjustment of central and local fiscal relations is not a problem of control and anti-control, but that of the order. If constructing better order, central and local fiscal relations should be regulated through complete rules.

China should regulate central and local fiscal relations through rational, definite, stable and compatible rules, which means the adjustment of rules. Because policy is the main method of adjusting and changing fiscal system, it is of great importance to coordinate the relations between policy and law in order to realize benign interactive between the central government and local governments. When solving the relations between policy and law, China should not replace policy with law easily, and China should construct rational, definite, stable and rules, which specifically includes the following aspects: (1) reinforcing the participation of the local governments during the process of formulating policy to avoid the adverse selection. (2) reinforcing the central supervision during the process of implementing policy to avoid the moral hazard. (3) propelling the transition from dominant policy adjustment to the dominant law adjustment and realizing the organic integration between standardization and flexibility . National People's Congress can organize the dispute between the central government and local governments, and make decisions by majority voting mechanism. After the rules are made, the central government can make implementation rules, which is beneficial for preventing the central government regulating fiscal system through administrative methods and resulting flexibility. 
4.2 Structural reasons and solutions for the endless cycle of power from centralization to decentralization in fiscal system

The endless cycle of power from centralization to decentralization and popular optimism also result from the powerful and beneficial relations between the central government and local governments being not rationalized. In order for preventing the bargaining between the central government and local governments, China should adjust the powerful and beneficial relations between the central government and local governments, and make win-win in the reciprocal influencing and restricting relations. Actually, fiscal system is the outcome of balancing the pros and cons of fiscal decentralization and fiscal centralization.

The adjustment of powerful and beneficial relations between the central government and local governments means reclassifying power. Because of the tradition of centralization, it is necessary for rationalizing central and local fiscal relations through coordinating centralization and decentralization, which means coordinating fiscal centralization and decentralization. When solving the relations between fiscal centralization and fiscal decentralization, China should not regard centralization or decentralization as the object, but rationalize powerful and beneficial relations between the central government and local governments, which can be listed as follows:

(1) the central government adjusting the configuration of fiscal revenues, and centralizing relative fiscal capacity. It is beneficial for macro control while the central government centralizes fiscal revenues. Generally speaking, there are two ways for the central government to centralize fiscal revenues. One is increasing central fiscal revenues directly, which means enlarging the tax base of central tax and shared tax or increase tax rate. Another is increasing central fiscal revenues indirectly, which means increasing the ratio of central fiscal revenues to total fiscal revenues while keeping current tax and fees burden. In China, the burden of enterprises and residents will be much heavier, and the regional burden of tax and fees will be enlarged when the central government centralizes fiscal resources through increasing tax and fees. Therefore, the main method of central government centralizing fiscal resources is increasing central fiscal revenues indirectly. It is necessary to adjust the configuration of fiscal revenues, which means extra-budgetary funds and extra-system funds should be included in fiscal revenues. On this basis, China should increase the ratio of central fiscal revenues to total fiscal revenues according to the division of responsibility between the central government and local governments.

(2) the central government transferring the responsibility. It is beneficial for the local governments to provide public services while the central government transfers the responsibility. It is necessary to divide the responsibility between the central government and local governments. As for the responsibility cooperated by the central government and local governments, China should make sure that which level of government be in charge of making standard of public services, collecting funds for public services, and providing public services. ${ }^{[4]}$

(3) the central government sticking to the coordination between the responsibility and the fiscal power, and transferring the fiscal power. During the process of transferring fiscal power, the central government should insist on the principle of the responsibility for public services matching fiscal power, and the responsibility for expenditure matching financial resources. The core of fiscal power is tax power, and the core of tax power is tax legislative power. Therefore, the key of the central government transferring fiscal power is to enlarge tax legislative power of local governments. During the process of transferring tax legislative power, the central government should have an overall program and transfer the tax legislative power step by step. Generally speaking, as for tax influencing national economy, whose tax legislative power should belong to the central government in order to ensure the capacity of macro control from the central government. As for tax inclusive of local benefit, tax legislative power should belong to local governments.

(4) the central government adjusting the configuration of fiscal transfer, and executing fiscal regulation. During the process of the central government transferring responsibility and fiscal power, the central government should control the behaviors of local governments through fiscal methods rather than administrative methods. As for the model of fiscal transfer, China should think of the vertical as the key while combining with the horizontal, which will be beneficial for narrowing the regional developmental imbalance and relieving the fiscal burden of the central government. At the same time, China should adjust the structure of general fiscal transfer, narrow until cancel irregular tax refund, and enlarge general fiscal transfer step by step. In addition, China should improve the distributing methods of special fiscal transfer. If local governments can not use special fiscal transfer according to the intention of the central government, the central government can terminate or recall funding. As for new special fiscal transfer, China should combine the small special fiscal transfer to a big one. In specific, China should construct strict assessing mechanism, regulate definitely the conditions and standards while local governments accepting special fiscal transfer in order for preventing randomness and blindness. Meanwhile, China should form regulated funds allocation mechanism, and choose different allocating methods according to different situations of local governments. In addition, China should construct strict supervising mechanism in order for preventing optimistic behaviors of local governments and make sure that the funds are used efficiently.

\section{References}

[1] Zhiyong Chen, "Relations between taxes and fees and the construction of local government revenue system,” Taxation Research, 2000(6) , pp. 2528.

[2] Jiwei Lou, "50 years of financial statistics since PRC was founded," Peking: Economic Science Press, 2000, pp. 157-158.

[3] Shaoguang Wang, "Bottom line of decentralization," Peking: China Planning Press, 1997, p. 122.

[4] Christine P. W. Wong etc. "China: National Development and SubNational Finance,” Peking: China Citic Press, 2003, p. 8. 